\title{
INFESTAREA BOARṬEI EUROPENE (RHODEUS AMARUS (BLOCH, 1782)) DIN RÂUL RĂUT CU CLINOSTOMUM COMPLANATUM (RUDOLPHI, 1814)
}

\author{
Gologan lon \\ Institutul de Zoologie al MECC, Chișinău, Republica Moldova \\ E-mail:gologanionel@gmail.com
}

https://doi.org/10.53937/9789975315975.43

Monitorizarea situației parazitologice și evaluarea dinamicii speciilor de paraziți potențiali patogeni atât pentru pești, cât și pentru om sunt deosebit de semnificative, deoarece au atât valoare teoretică, cât și valoare practică. Studiul sistematic al parazitofaunei peștilor face posibilă determinarea compoziției speciilor din bazinele acvatice analizate (Головина, 2014).

Clinostomum complanatum (Rudolphi, 1814) - trematod parazit, care în stadiul adult parazitează în tractul digestiv la animalele carnivore și la păsările ihtiofage (egrete, stârc, cormoran) (Aohagi, 1992, Наумова, 1989), iar în stadiul de metacercar în organele interne, țesutul muscular și tegument la pești. Stadiile larvare sporochist - redie - cercar se dezvoltă în moluștele acvatice (gazde intermediare) - Limnaea stagnalis și Radix ovata (Бayep, 1897). Sunt înregistrate cazuri de parazitism și la om, care poate parazita în faringe (Jung, 2015) și pe mucoasa laringeală (Park, 2009).

Clinostomum complanatum are lungimea corpului 4,8-5,1 mm. Capătul posterior rotunjit, iar cel anterior ușor tăiat. Ventuza ventrală este situată la limita dintre primul și al doilea sfert al corpului. Rudimentele sexuale bine dezvoltate sunt situate între ventuza ventrală și capătul posterior al corpului. Testiculele sunt triunghiulare sau au forma neregulată. Ovarul este rotunjit. În apropierea testiculului anterior este situată bursa cirusului. Uterul, sub forma unui tub îngust, aderă la mar- 
ginea stângă a testiculului anterior și se extinde spre ventuza ventrală, formând o curbură ce trece într-un sac extins (foto d).

Cercetărie efectuate pe parcursul anului 2017, privind studiul helmintofaunei la pești din râul Răut (satul Ustia), pentru prima dată a fost evidențiată specia de trematode Clinostomum complanatum (Rudolphi, 1814), la Boarța europeană în cavitatea branhială, țesut muscular, cavitatea corpului și țesut celular subcutanat (foto. b, c). Total; au fost supusi disecției parazitologice complete 105 exemplare de Boarță europeană (Rhodeus amarus (Bloch, 1782) (foto a) (syn.: Cyprinus amarus Bloch, 1782, Rhodeus sericeus amarus (Bloch, 1782), Rhodeus lucinae Walecki, 1863, Rhodeus genitalis Walecki, 1863). Extensivitatea invaziei fiind de 18,1\%, iar intensitatea invaziei variind în limita de 1-7 exemplare. Anterior, acest parazit a fost depistat la Cobitidae (Cobitis danubialis Bacescu, 1993, C. elongatoides Bacescu et Maier, 1969, C. tanaitica Bacescu et Maier, 1969, Sabanejewia balcanica (Karaman, 1922), S. bulgarica (Drensky, 1928), S. baltica Witkowski, 1994), Siluridae (Silurus glanis Linnaeus, 1758), Esocidae (Esox lucius L., 1758), Percidae (Perca fluviatilis L., 1758) și Odontobutidae (Percottus glenii Dybowski, 1877) (Moșu, 2014).

Materialul parazitologic a fost fixat în etanol 70\% și formol 2\%. Atât paraziții vii, cât și cei fixați au fost examinați la microscopul optic și cu videoadapter NOVEX HOLLAND. Preparatele totale au fost efectuate conform metodelor clasice descrise în literatura de specialitate (Куклин, 2013, Быховская-Павловская, 1985). Preparatele totale sunt păstrate în colecția de preparate din cadrul Laboratorului de Parazitologie și Helmintologie al Institutului de Zoologie al MECC. 